Jurnal Natur Indonesia 13(1), Oktober 2010: 1-6

ISSN 1410-9379, Keputusan Akreditasi No 65a/DIKTI/Kep./2008

\title{
Pembuatan Membran Polimer Elektrolit Berbasis Polistiren Akrilonitril (SAN) untuk Aplikasi Direct Methanol Fuel Cell
}

\author{
Irwan Ginting Suka ${ }^{1 *}$, Wasinton Simanjuntak ${ }^{11}$, dan Eniya Listiani Dewi²) \\ 1)Jurusan Kimia, Fakultas Matematika IImu Pengetahuan Alam Universitas Lampung, Bandar Lampung 35145 \\ 2)Pusat Teknologi Material, Badan Pengkajian dan Penerapan Teknologi, \\ JI. MH. Thamrin 8, BPPT II, Lt. 22, Jakarta. 10340
}

Diterima 13-03-2009 Disetujui 22-02-2010

\begin{abstract}
In this study, electrolyte membranes based on polystyrene acrylonitrile (SAN) for Direct Methanol Fuel Cell application were prepared. The preparation was carried out in two steps. The first step was introduction of additives, silica and zeolite, as reinforcing agent on SAN, to obtain silica-reinforced SAN membrane, specified as SAN-Si, and zeolite-reinforced SAN membranae, specified as SAN-Z. The two reinforced membranes were then subjected to sulphonation using sulphuric acid, and the sulphonated membranes are specified as S-SAN-Si and S-SAN-Z, respectively. The characteristics of the membrane were described in terms of the degree of sulphonation, ionic conductivity, methanol permeability, and percentage of swelling in water and methanol. The results obtained demonstrated that additives result in significant reduction of methanol crossover, as reflected by lower values of methanol permeability than that obtained for the membrane without additive. It was also found that zeolite functions relatively better than silica. For zeolite-modified membrane (S-SAN-Z) the ionic conductivity of $10.05 \times 10^{-6} \mathrm{~S} / \mathrm{cm}$ was achieved. The membrane also marked by methanol permeability of $0.52 \times 10^{-6}$, percentage of swelling of $5.12 \%$ in water and $2.58 \%$ in methanol. Thermal analysis using DSC technique revealed changes in glass transition from the original sample, in which the glass transition of the original sample, SAN, $\left(55^{\circ} \mathrm{C}\right)$, sulphonated SAN, S-SAN, $\left(83.36^{\circ} \mathrm{C}\right)$, silica-modified membrane S-SAN-Si $\left(79.86^{\circ} \mathrm{C}\right)$, and zeolite-modified membrane S-SAN-Z $\left(79.29^{\circ} \mathrm{C}\right)$. Addition of additive was also found to influence the surface characteristics of the membranes as revealed by SEM analysis, in which the surface changed from smooth for the original sample into rough for the reinforced samples with both additives.
\end{abstract}

Keywords: additive, direct methanol fuel cell, ionic conductivity, methanol cross-over, styrene-acrylonitrile, sulphonation.

\section{PENDAHULUAN}

Krisis energi merupakan salah satu tantangan paling berat yang dihadapi manusia dewasa ini karena semakin menipisnya cadangan sumber energi fosil, sementara kebutuhan akan energi terus mengalami peningkatan seiring dengan perkembangan aktifitas manusia. Kenyataan ini telah mendorong penelitian untuk pengembangan beragam sumber energi alternatif di berbagai negara di dunia, salah satunya adalah sel bahan bakar (Fuel Cell) (Prater, 1994; Bossel, 2000). Prinsip kerja sel bahan bakar sangat mirip sekali dengan baterai (accu) dimana keduanya sama-sama mempunyai komponen utama elektroda dan elektrolit. Dalam sel bahan bakar, membran elektrolit merupakan komponen utama yang berperan untuk memisahkan reaktan dan menjadi sarana transportasi ion hidrogen yang dihasilkan oleh reaksi anoda menuju katoda sehingga reaksi katoda yang menghasilkan energi listrik dapat terjadi (Carette et al., 2001; Bossel, 2000). *Telp: +6281369068291

Email: irwanginting@yahoo.com
Berdasarkan jenis elektrolit yang digunakan, salah satu jenis sel bahan bakar yang sedang diteliti secara intensif adalah sel dengan bahan bakar metanol, sehingga dikenal secara luas sebagai Direct Methanol Fuel Cell (DMFC) (Appleby \& Foulkes, 1989). Direct Methanol Fuel Cell (DMFC) menggunakan polimer sebagai membran elektrolit dan biasanya sel ini beroperasi pada suhu kamar dengan kerapatan daya yang cukup tinggi. Karena sifat-sifat ini, DMFC mempunyai peluang aplikasi yang besar berbagai bidang, seperti transportasi, pembangkit listrik, dan perangkat elektronik portable (Antonucci et al., 1999; Yohan, 2005).

Saat ini membran yang digunakan terbuat dari fluoro-polimer dengan rantai cabang mengandung gugus sulfonat, salah satunya adalah politetrafluoroetilena (PTFE) tersulfonasi, yang dikenal dengan nama dagang Nafion (Dupont, 1996). Namun permasalahan utama dari Nafion untuk pemakaian pada DMFC yaitu adanya permeasi metanol melalui membran (methanol crossover) yang sulit dihindari, permeabilitas metanol 
untuk Nafion $4,9 \times 10^{-6} \mathrm{~cm}^{2} / \mathrm{s}$. Nafion juga termasuk dalam polimer yang mahal sehingga penggunaan terhadap bahan ini menjadi kendala untuk mengkomersialkan DMFC (Antonucci et al., 1999; Jung, 2002; Dewi, 2007). Oleh karena itu perlu dilakukan penelitian yang mendasar dan sistematik guna mendapatkan membran alternatif yang di satu sisi mempunyai efisiensi pemisahan yang tinggi dan di sisi lain sangat ekonomis.

Selain jenis Nafion, jenis polimer non-Nafion atau jenis hidrokarbon yang tidak mengandung Flourin telah banyak dikembangkan, misalnya jenis polyimide, polysulfone, polycarbonate, polyeter-ether keton (Handayani et al., 2007) sPSf/PBI (Kerres, 2001) sPEEK/PBI (Hasiotis et al., 2001), sPSf/PES,sPEEK/ PES (Manea \& Mulder, 2001), styrene-butadiene (Savadogo, 2004) dengan ketahanan pada Polymer Electrolyt Fuel Cell (PEFC) selama 4000 jam, dan acrylamide sulfonic acid (Dewi, 2007). Namun sulfonasi jenis polistiren akrilonitril (SAN) belum pernah dilakukan, dengan mengacu pada proses sulfonasi gugus stiren, maka dimungkinkan untuk membuat SAN menjadi membran elektrolit padat polimer. Adanya gugus sulfonat $\left(\mathrm{SO}_{3} \mathrm{H}\right)$ pada SAN akan menyebabkan polimer bersifat hidrofilik. Artinya, apabila bercampur dengan air atau bahan polar lainnya, maka polimer ini akan mudah membentuk ikatan hidrogen dan dapat larut didalamnya.

Dalam penelitian ini dilakukan sulfonasi polistiren akrilonitril (SAN) untuk digunakan sebagai membran polimer elektrolit untuk aplikasi Direct Methanol Fuel Cell. Sulfonasi pada membran SAN, optimum pada konsentrasi asam sulfat $\left(\mathrm{H}_{2} \mathrm{SO}_{4}\right) 10 \mathrm{M}$ dan suhu $60^{\circ} \mathrm{C}$ (Irwan et al., 2007). Penelitian ini bertujuan untuk mempelajari pengaruh penambahan additif anorganik seperti silika dan zeolit terhadap karakteristik poliSAN tersulfonasi sebagai membran Direct Methanol Fuel Cell (DMFC). Silika diketahui mempunyai kestabilan mekanis yang tinggi, daya tahan terhadap zat kimia, dan konduktivitas tinggi, sehingga dapat meningkatkan konduktivitas membran (Kreuer, 1996; Depre et al., 2000; Baradie 2000 et al., Honma et al., 2001). Fungsi penambahan zeolit pada membran SAN agar dapat meminimalisasi methanol crossover. Hal ini disebabkan volume dan ukuran garis tengah ruang kosong dalam kristal zeolit yang menjadi dasar penggunaan zeolit sebagai bahan penyaring molekul. Molekul zat yang ukurannya lebih kecil dari ukuran garis tengah ruang kosong mineral zeolit dapat melintas, sedangkan yang berukuran lebih besar akan tertahan atau tertolak (Breck, 1974). Pengujian sifat membran polimer elektrolit dilakukan dengan melihat konduktivitas ionik membran, permeabilitas methanol dan uji swelling pelarut air dan metanol. Karakterisasi membran dilakukan dengan analisis termal menggunakan Differential Scanning Calorimetri (DSC) dan analisis profil permukaan membran dengan Scanning Electron Microscopy (SEM).

\section{BAHAN DAN METODE}

Bahan-bahan yang digunakan adalah polistiren akrilonitril (SAN) diproduksi oleh PT. Risdjaj Brasali, Cilegon, Indonesia, etil metil keton, asam sulfat, silika, $\mathrm{H}$-zeolit, aquades, natrium hidroksida, indikator universal, dan metanol.

Alat-alat yang digunakan dalam penelitian adalah neraca analitik, oven vakum, hot plate, termometer, stirer, stopwatch, plat kaca, alat kaca membran, instrumen DSC (Perkin Elmer, Pyris 6 series), perangkat EIS (Autolab PGSTAT 30), perangkat SEM (JEOL JSM/ 6510 LA), Spektrofotometer FTIR (Varian/Schimitar, 2000), water bath ultrasonic, alat uji permeabilitas, dan alat-alat gelas yang umum digunakan dalam laboratorium.

Metode. Preparasi membran SAN dengan aditif silika (SAN-Si) dan membran SAN dengan aditif zeolit (SAN-Z). Untuk pembuatan membran dengan aditif silika (SAN-Si), sebanyak 15 gram SAN dilarutkan dengan $50 \mathrm{ml}$ etil metil keton, Ialu ditambahkan silika sebanyak 0,45 gram. Campuran tersebut diaduk dengan menggunakan stirer, setelah itu dibiarkan selama 24 jam pada suhu kamar. Selanjutnya sampel dimasukkan ke water bath ultrasonic selama 15 menit. Kemudian dicetak dengan ketebalan basah $1 \mathrm{~cm}$, dan dikeringkan dalam oven pada suhu $80^{\circ} \mathrm{C}$. Prosedur yang sama digunakan untuk pembuatan membran SAN dengan aditif zeolit (SAN-Z).

Sulfonasi membran. Membran SAN-Si dan SAN-Z yang didapatkan selanjutnya disulfonasi menggunakan asam sulfat $10 \mathrm{M}$, suhu $60^{\circ} \mathrm{C}$, dan waktu reaksi 5 jam, menerapkan prosedur yang telah dijelaskan dalam penelitian sebelumnya (Irwan et al., 2007). 
Karakterisasi membran. Uji konduktivitas ionik, Uji konduktivitas dilakukan dengan metode impedansi kompleks spektroskopi untuk mengetahui adanya ion-ion $\mathrm{H}^{+}$dalam sampel, sebagai indikator sifat penukar kation dari membran (membran elektrolit). Uji ini dilakukan menggunakan alat Electrochemical Impedance Spectroscopy (EIS).

Uji permeabilitas metanol. Untuk melakukan uji permeabilitas metanol, prosedur yang dilakukan adalah sebagai berikut: Sampel membran yang kering dimasukkan ke dalam tempatnya di antara dua kolom. Metanol dengan konsentrasi $2 \mathrm{M}$ dimasukkan ke kolom A dan air ke kolom B. Metanol dan air distirer selama 6 jam. Larutan dikolom A dan B dihitung densitasnya pada $\mathrm{t}=0$ dan $\mathrm{t}=6$ jam. Permeabilitas metanol ditentukan dengan pengukuran transfer metanol yang melewati membran polimer elektrolit.

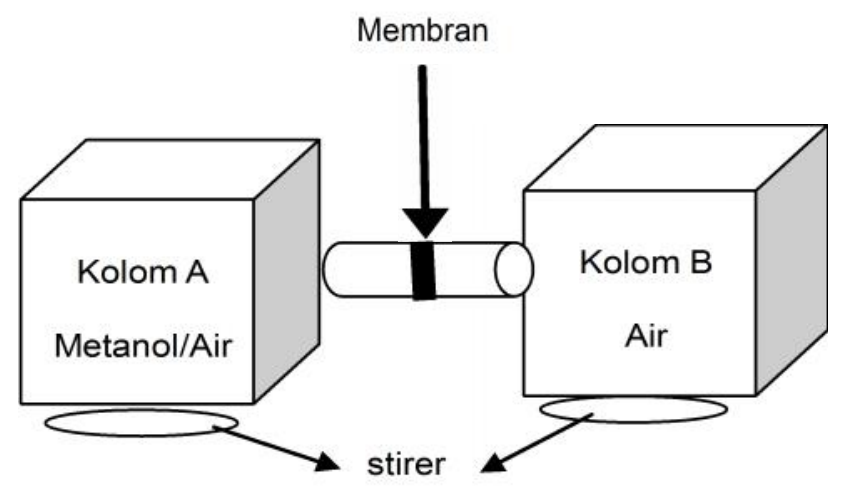

Gambar 1. Skema alat uji permeabilitas

Nilai permeabilitas metanol dapat dihitung melalui persamaan (8) berikut:

Permeabilitas metanol $=\frac{\left(\mathrm{C}_{\mathrm{B}}(\mathrm{t}) \times \mathrm{V}_{\mathrm{B}} \times \mathrm{L}\right)}{\left(\mathrm{t} \times \mathrm{A} \times \mathrm{C}_{\mathrm{A}}\right)}$

dengan $C_{B}(t)=$ Konsentrasi metanol pada kolom $B$ pada $\mathrm{t}=6 \mathrm{jam}\left(\mathrm{mol} / \mathrm{cm}^{3}\right) ; \mathrm{V}_{\mathrm{B}}=$ Volume larutan pada kolom $\mathrm{B}$ $\left(\mathrm{cm}^{3}\right) ; \mathrm{L}=$ Tebal membran; $\mathrm{t}=$ waktu operasi (detik); $\mathrm{A}$ $=$ Luas membran $\left(\mathrm{cm}^{2}\right)$ dan $\mathrm{C}_{\mathrm{A}}:$ Konsentrasi metanol pada kolom A pada $\mathrm{t}=0\left(\mathrm{~mol} / \mathrm{cm}^{3}\right)$.

Uji termal. Pengujian ini dilakukan menggunakan Differential Scanning Calorimetry (DSC) (Perkin Elmer, Pyris 6 series). Alat penguji terdiri dari sebuah tempat uji yang dihubungkan dengan komputer. Dari pengujian DSC, sifat termal dari bahan dapat dilihat dari grafik yang akan muncul dari layar komputer. Pada uji termal ini akan diukur transisi kaca (tg) yaitu suhu terjadinya perubahan bahan dalam bentuk glass (padat) ke bentuk rubber.
Uji swelling terhadap air dan methanol. Uji swelling dilakukan untuk mengetahui banyaknya zat atau bahan yang dapat diserap oleh membran. Dalam penelitian ini dilakukan uji swelling terhadap air dan metanol (1 M). Membran dikeringkan dalam oven vakum pada suhu $60^{\circ} \mathrm{C}$ selama 48 jam kemudian ditimbang dan diperoleh berat kering membran $\left(\mathrm{W}_{\text {dry }}\right)$. Kemudian membran direndam dalam air atau metanol selama 24 jam pada suhu kamar. Setelah air atau metanol dipisahkan dari sampel, berat basah membran $\left(\mathrm{W}_{\text {wet }}\right)$ ditimbang.

$$
\% \text { Swelling }=\frac{(\mathrm{W} \text { wet }- \text { Wdry })}{\text { Wdry }} x 100 \%
$$

Uji kualitatif menggunakan SEM. Karakterisasi dengan SEM (JEOL JSM/6510 LA) dilakukan dengan tujuan untuk melihat fotomorfologi membran SAN tersulfonasi (S-SAN), membran SAN aditif silika tersulfonasi (S-SAN-Si), membran SAN aditif zeolit tersulfonasi (S-SAN-Z). Dengan cara ini, dapat diketahui karakteristik porositas membran.

\section{HASIL DAN PEMBAHASAN}

Polistiren akrilonitril (SAN) merupakan polimer hidrofobik, sehingga memerlukan modifikasi agar sifatsifatnya dapat memenuhi persyaratan sebagai membran sel bahan bakar. Untuk tujuan tersebut, salah satu teknik yang sedang dikembangkan adalah sulfonasi, yakni pemberian gugus sulfonat pada polimer. Dari penelitian sebelumnya diketahui bahwa sulfonasi pada membran SAN, optimum pada konsentrasi asam sulfat $\left(\mathrm{H}_{2} \mathrm{SO}_{4}\right) 10 \mathrm{M}$ dan suhu $60^{\circ} \mathrm{C}$ (Irwan et al., 2007).

\section{Sulfonasi membran SAN aditif silika (SAN-Si)} dan SAN aditif zeolit (SAN-Z). Sulfonasi membran SAN-Si didasarkan bahwa membran dengan bahan baku silika diketahui memiliki kestabilan mekanis, panas, kimiawi, dan konduktifitas ionik yang baik sehingga telah diuji coba sebagai komposit dan hibrida dengan membran organik dalam pemanfaatannya sebagai membran dalam sel bahan bakar bermembran polimer elektrolit (Honma et al., 2001). Sedangkan membran dengan bahan baku zeolit diharapkan dapat berfungsi sebagai bahan yang dapat menyerap air maupun metanol dan menurunkan permeabilitas metanol, dengan adanya pori pada zeolit dapat menahan metanol pada membran sehingga permeabilitas metanol akan lebih kecil dibanding dengan tanpa penambahan aditif. Tipe zeolit yang dipilih adalah, 
$\mathrm{H}$-zeolit yang mempunyai kation yang dapat dipertukarkan yaitu ion $\mathrm{H}^{+}$, sehingga dapat berfungsi sebagai konduktor proton yang menghasilkan konduktivitas proton yang tinggi. Hal ini disebabkan volume dan ukuran garis tengah ruang kosong dalam kristal zeolit yang menjadi dasar penggunaan sebagai bahan penyaring molekul (Hartanto et al., 2007). Tabel 1 menunjukkan nilai pengujian membran SAN-Si dan SAN-Z tersulfonasi.

Dari Tabel 1 dapat dilihat bahwa konduktivitas ionik membran S-SAN aditif silika maupun zeolit lebih rendah bila dibandingkan dengan S-SAN $\left(1,04 \times 10^{-5}\right)$. Menurut Jung (2002), konduktivitas ionik membran aditif seharusnya lebih tinggi dibandingkan membran tanpa aditif. Hal ini disebabkan baik silika maupun zeolit dapat menyerap air yang berfungsi sebagai media transport proton pada sulfonat sehingga konduktivitas ionik akan meningkat. Dalam penelitian ini aditif yang digunakan sebanyak 3\%, diperkirakan jumlah aditif yang ditambahkan terlalu banyak, sehingga memberikan nilai konduktivitas kecil (Arimura et al., 1999). Penambahan aditif yang terlalu berlebih dapat menyebabkan tertutupnya gugus sulfonat sehingga mengganggu peran sulfonat sebagai penghantar proton. Selain itu penambahan aditif silika yang berlebih dapat menyebabkan terjadinya asam lemah yakni asam silikat dengan konsentrasi asam semakin pekat dan ion $\mathrm{H}^{+}$yang terdisosiasi semakin berkurang dapat menyebabkan konduktivitas ionik semakin kecil.

Berdasarkan Tabel 1 terlihat bahwa membran S-SAN-Si dan S-SAN-Z mempunyai permeabilitas metanol yang lebih rendah bila dibandingkan dengan membran S-SAN $\left(1,96 \times 10^{-6}\right)$. Hal ini dapat dijelaskan bahwa silika pada membran S-SAN-Si dapat menyerap metanol pada permukaan membran sehingga sebagian besar metanol tidak melewati membran. Selain itu penambahan silika dapat menutup pori pada membran sehingga pindahnya metanol melalui membran sangat kecil. Penurunan permeabilitas metanol membran SSAN-Z disebabkan volume dan ukuran garis tengah ruang kosong kristal zeolit diperkirakan lebih kecil

Tabel 1. Nilai pengujian membran S-SAN-Si dan S-SAN-Z

\begin{tabular}{lccc}
\hline \multirow{2}{*}{ Parameter pengujian membran } & \multicolumn{2}{c}{ Jenis membran } \\
\cline { 3 - 3 } Swelling terhadap air (\%) & S-SAN-Si & S-SAN-Z \\
Swelling terhadap metanol (\%) & 4,13 & 5,12 \\
Konduktivitas ionik (S/cm) & 2,21 & 2,58 \\
Permeabilitas metanol (cm $/$ detik) & $1,49 \times 10^{-6}$ & $10,05 \times 10^{-6}$ & $0,52 \times 10^{-6}$ \\
\hline
\end{tabular}

dibandingkan ukuran molekul metanol sehingga molekul metanol tidak dapat melintas pada membran. Hal ini juga yang menyebabkan nilai permeabilitas metanol S-SAN-Z lebih rendah dibandingkan S-SAN-Si, karena diperkirakan ukuran pori-pori membran S-SAN-Z lebih kecil dibandingkan membran S-SAN-Si.

Sebagai pembanding terhadap nilai pengujian membran S-SAN-Si dan S-SAN-Z di atas, maka pengujian yang sama dilakukan terhadap membran nafion. Tabel 2 menunjukkan beberapa nilai pengujian terhadap membran nafion.

Dari Tabel 2 tersebut, diketahui nilai konduktivitas ionik membran nafion sebesar $1 \times 10^{-1} \mathrm{~S} / \mathrm{cm}$. Nilai ini lebih besar bila dibandingkan dengan nilai konduktivitas ionik membran S-SAN yaitu sebesar $1,04 \times 10^{-5} \mathrm{~S} / \mathrm{cm}$. Bila dilihat dari strukturnya (Gambar 1), nafion memiliki banyak atom flour (F) yang mempunyai nilai keelektronegatifan yang besar sehingga nafion dapat dengan mudah membentuk ikatan hidrogen dengan air (mudah menyerap air) sehingga nilai konduktivitas ioniknya menjadi besar karena air berperan sebagai media transfer proton.

Meskipun nilai konduktivitas ionik membran S-SAN lebih kecil dibanding nafion, tetapi membran ini masih dapat digunakan untuk aplikasi pada DMFC, artinya membran masih dapat menghantarkan proton walaupun berjalan lambat. Dimana rentang nilai konduktivitas ionik membran untuk aplikasi DMFC terbagi menjadi dua, yaitu $10^{-1}-10^{-2}$ yang merupakan nilai konduktivitas ionik besar, sedangkan untuk nilai konduktivitas ionik sebesar $10^{-3}-10^{-5}$ termasuk nilai konduktivitas ionik

Tabel 2. Nilai pengujian membran nafion.

\begin{tabular}{lc}
\hline \multicolumn{1}{c}{ Parameter Uji } & Nilai Uji \\
\hline Derajat sulfonasi (\%) & 100 \\
Swelling terhadap air (\%) & 19 \\
Swelling terhadap metanol (\%) & 9,6 \\
Konduktivitas ionik (S/cm) & 0,1 \\
Permeabilitas metanol (cm $/$ detik) & $4,9 \times 10^{-6}$ \\
\hline
\end{tabular}

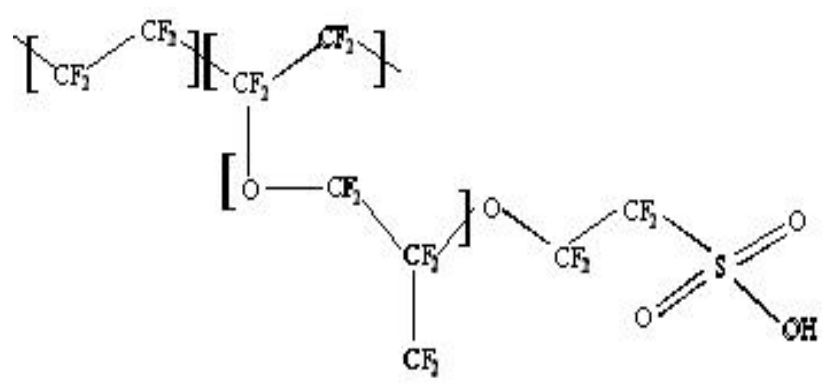

Gambar 1. Struktur nafion 
kecil (Anita \& Desriana, 2006; Yohan, 2005). Dari Tabel 2 juga diketahui bahwa nilai permeabilitas metanol nafion sebesar $4,9 \times 10^{-5} \mathrm{~cm}^{2} /$ detik. Bila dibandingkan dengan nilai permeabilitas metanol membran S-SAN $\left(1,04 \times 10^{-5} \mathrm{~cm}^{2} /\right.$ detik), jelas bahwa nilai permeabilitas metanol nafion lebih besar dibandingkan dengan membran S-SAN. Hal ini dapat dijelaskan bahwa meskipun nafion dan S-SAN aditif sama-sama bersifat hidrofilik, namun diperkirakan hidrofilitas nafion lebih tinggi dibandingkan S-SAN. Kandungan atom flour (F) yang terdapat pada nafion lebih bersifat elektronegatif daripada atom oksigen $(O)$ pada S-SAN, sehingga nafion dapat dengan mudah membentuk ikatan hidrogen dengan metanol.

Uji termal. Untuk mempelajari pengaruh suhu pada membran, dilakukan pengujian menggunakan alat Differential Scanning Calorimetry (DSC). Kurva DSC sampel membran baik untuk S-SAN, S-SAN-Si dan S-SAN-Z diperlihatkan oleh Gambar 2. Polistryrenakrilonitril diketahui mempunyai suhu transisi kaca $(\mathrm{Tg})$ $55^{\circ} \mathrm{C}$ (Yohan, 2005). Dari hasil pengujian didapat suhu transisi kaca pada sampel membran SAN terjadi pada suhu $83,36^{\circ} \mathrm{C}$, membran SAN-Si sebesar $79,86^{\circ} \mathrm{C}$, dan SAN-Z terjadi pada suhu $79,29^{\circ} \mathrm{C}$.

Hal ini disebabkan membran SAN mengalami proses sulfonasi yakni terikatnya gugus sulfonat yang dapat membuat sifat membran menjadi lebih kaku sehingga lebih tahan terhadap panas.
Uji kualitatif menggunakan SEM. Gambar. 3 menunjukkan struktur morfologi dari membran S-SAN, S-SAN-Si, dan S-SAN-Z menggunakan SEM dengan perbesaran 1000 kali.

Membran SAN tersulfonasi (S-SAN) merupakan membran tembus pandang atau transparan jika dilihat secara visual. Pengujian SEM terhadap membran secara cross section, menunjukkan bahwa morfologi membran terlihat halus dan sedikit bergelombang. Sedangkan untuk membran aditif silika dan zeolit memperlihatkan perubahan morfologi membran yang cukup signifikan. Permukaan kedua membran S-SAN aditif (Gambar 3b dan 3c) terlihat lebih kasar dan bergelombang dibandingkan membran S-SAN tanpa aditif (Gambar 3a). Hal ini mengindikasikan bahwa aditif terdistribusi secara merata pada permukaan membran.

\section{KESIMPULAN}

Berdasarkan penelitian yang telah dilakukan, dapat diambil kesimpulan bahwa penambahan aditif pada membran SAN dapat mengurangi methanol crossover, dibuktikan dengan nilai permeabilitas metanol yang lebih kecil dibandingkan dengan membran SAN tanpa aditif. Hasil analisis menggunakan SEM menunjukkan morfologi permukaan membran SAN terlihat halus dan sedikit bergelombang, sedangkan untuk sampel membran SAN aditif silika dan zeolit memperlihatkan perubahan morfologi yang lebih kasar
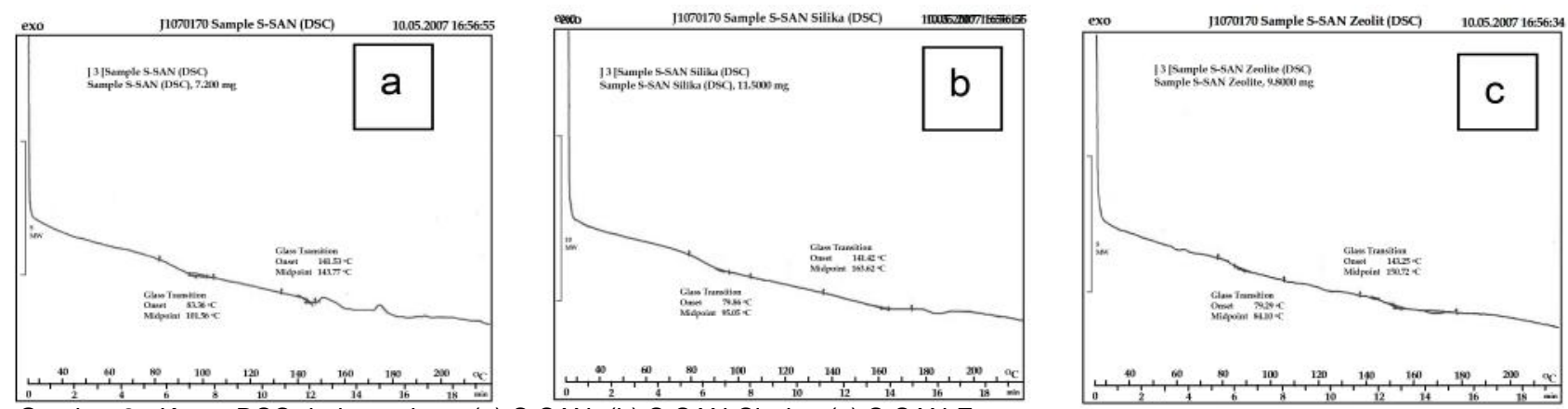

Gambar 2. Kurva DSC dari membran (a) S-SAN, (b) S-SAN-Si, dan (c) S-SAN-Z
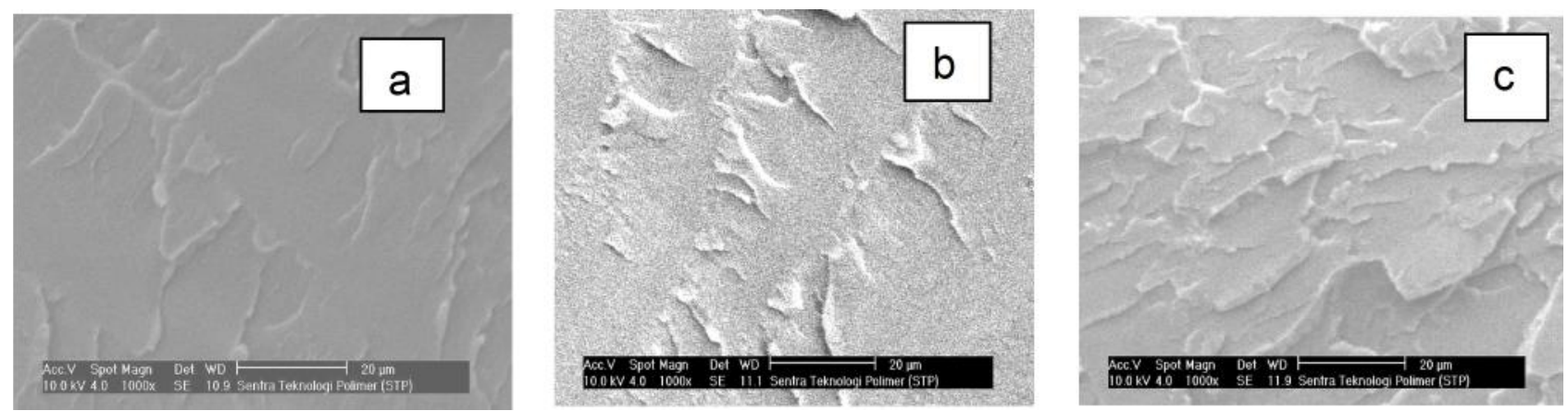

Gambar 3. Struktur morfologi dari membran (a) S-SAN, (b) S-SAN-Si, dan (c) S-SAN-Z. 
dan bergelombang. Secara keseluruhan, zeolit berfungsi lebih baik dibanding silika. Membran dengan aditif zeolit ditemukan memiliki konduktifitas ionik sebesar $10,05 \times 10^{-6} \mathrm{~S} / \mathrm{cm}$, dan permeabilitas metanol sebesar $0,52 \times 10^{-6} \mathrm{~cm}^{2} /$ detik. Pengaruh aditif juga ditunjukkan oleh perubahan suhu transisi gelas, dimana untuk SAN asli nilai yang diperoleh adalah $55^{\circ} \mathrm{C}$, sementara nilai untuk SAN-tersulfonasi (S-SAN) adalah $83,36^{\circ} \mathrm{C}$, membran dengan aditif silika S-SAN-Si adalah $79,86^{\circ} \mathrm{C}$, dan membran dengan aditif zeolit S-SAN-Z adalah $79,29^{\circ} \mathrm{C}$.

\section{UCAPAN TERIMA KASIH}

Pada kesempatan ini penulis menyampaikan Terima Kasih dan Penghargaan kepada Kementerian Negara Riset Dasar/RD-2007-001/SK/PPK/BE/BPPT/ I/2007 dan RD-2008-003/SK/PPK/BE/BPPT/I/2008.

\section{DAFTAR PUSTAKA}

Anita, H. \& Desriana, T.U. 2006. Mempelajari pengaruh pencampuran (Blending) PEEK tersulfonasi dengan polisulfon untuk Aplikasi Membran Elektrolit. Laporan Penelitian. Jurusan Teknik Kimia Fakultas Teknologi Industri. Institut Teknologi Indonesia. Tangerang.

Antonucci, P.L., Arico, A.S., Creti, P., Ramunni, E. \& Antonucci, V. 1999. Investigation of a direct methanol fuel cell based on a composite nafion-Silika Electrolyte for High Temperature Operation. Solid State Ionics 125: 431-439.

Appleby, A.J. \& Foulkes, F.R. 1989. Fuel Cells Handbook Van Nostrand Reinhold, New York.

Baradie, B., Dodelet, J.P. \& Guay, D. 2000. Hybrid nafioninorganic membrane With Potensial Applications for Polymer Electrolyte Fuel Cells. Journal of Electroanalitical Chemistry 489: 101-105.

Bossel, U. 2000. The birth of the Fuel Cell; European Fuel Cell Forum: Oberrohrdorf.

Breck, D.W. 1974. Zeolite Molecular Sievies. Didalam Sutarti, dkk. Zeolit Tinjauan Literatur. Pusat dokumentasi dan informasi ilmiah. Lembaga IImu Pengetahuan Indonesia.

Carette, L., Friedrich, K. A. \& Stimming, U. 2001. Fuel CellFundamentals and Application. Wiley Online Library.

Depre, L., Ingram, M., Poinsignon, C. \& Popall, M. 2000. Proton conducting sulfon/sulfonamide functionalized materials based on inorganic-organic matrices. Electrochimica acta 45: 1377-1383.

Dewi, E.L. 2007, Development of local components for fuel cell Technology, Jurnal Sains Materi Indonesia 9: 57-66.

Dupont. 1996. Nafion ${ }^{\circledR}$, Technical information data sheet, Global customer service.

Handayani, S., Dewi, E. L., Purwanto, W. W. \& Roekmijati, W. S. 2007. Membran komposit polyeter Eter Keton yang Tersulfonasi-Zeolite untuk Aplikasi Sel Bahan Bakar Metanol Lansung. Jurnal Sains Materi Indonesia 9: 52-56.

Hartanto, S., Marlina, L. \& Handayani, S. 2007. Pengaruh Silika pada Membran Elektrolit Berbasis Polieter-eter Keton. Seminar Nasional Teknik Rekayasa Industri. T4-14:1-4. Jurusan Teknik Kimia. Fakultas Teknik Industri. Institut Teknologi Indonesia. Tangerang.

Hasiotis, C., Deimede, V. \& Kontoyannis, C. 2001. New Polymer Electrolytes based on Blends Sulfonated Polysulfone with Polybenzimidazole. Electrochimica Acta, 46: $2410-2406$

Honma, I., Nomura, S. \& Nakajima, H. 2001. Protonic Conducting Organic/ Inorganic Nanocomposites for Polymer Electrolyte Membrane. Journal of Membrane Science. 185: 83-94.

Irwan, G.S., Suprayitno, A. \& Simanjuntak, W. 2007. Sulfonasi Polistiren Akrilonitril Sebagai Membran Polimer Elektrolit Direct Methanol Fuel Cell. Jurnal IImiah MIPA BKS-PTN WILAYAH INDONESIA BARAT. 10: 97-103.

Jung, D.H. 2002. Performance evaluation of a nafion/silicon oxide hybrid Membranes for direct Methanol Fuel Cell. Journal of Power Sources 106: 173-177.

Kerres, J.A. 2001. Development of lonomer membranes for fuel cells. Journal of Membrane Science 185: 3-27.

Kreuer, K.D. 1996. Proton Conductivity: Materials and Applications. Chem. Mater 8: 610-641.

Manea, C. \& Mulder, M. 2002. Characterization of polymer blends of polyethersulfone/sulfonated polysulfone and polyethersulfone/Sulfonated polyetheretherketone for Direct Methanol Fuel Cell Aplications. Journal of Membrane Science 206: 443-453.

Prater, K.B. 1994. Polymer electrolyte Fuel Cell: A Review of Recent Development. Journal of Power Sources 51: 129131.

Savadogo, O. 2004. Emerging membranes for electrochemical systems Part II. high Temperature Composite Membranes for Polymer Electrolyte Fuel Cell (PEFC) Aplications. Journal of Power Source 127: 135-161.

Yohan, R.M. 2005. Pembuatan Bahan Membran Sel Bahan Bakar: Pengaruh Pengkondisian Film PTFE Terhadap Hasil Pencangkokan dengan Tekhnik Iradiasi Awal. Departemen Metalurgi dan Material. Fakultas Teknik Universitas Indonesia. Depok. 